\title{
Implementation of Islamic Religious Education Curriculum
}

\author{
Hambali Alman Nasution \\ UIN Sunan Kalijaga Yogyakarta \\ hambalialmannasution@gmail.com
}

\begin{abstract}
The changing times have an impact on all countries. With the changing times, the human mindset has also changed. The changing times bring positive and negative. The negative impact of globalization that seems sad is the change that tends to lead to a moral and moral crisis. The purpose of this study is to determine the implementation of the Islamic religious education curriculum and the obstacles and solutions to its implementation in the moral dimension. The method in this research is to use a descriptive qualitative approach. Data collection was carried out by means of interviews, observation and documentation. The results showed that the implementation of the Islamic religious education curriculum at SMA Negeri 2 Kotapinang was carried out well, by being able to develop religious knowledge so that it was carried out in their daily (religious) lives. Supported by activities carried out in schools such as: Jenazab Prayers, Speeches, Musabaqab Tilawatil Qur'an (MTQ), Rohis, Clean Living Principles and discipline of students who foster religious values.
\end{abstract}

Keywords: Curriculum Implementation, Islamic Religius Education, High School

\begin{abstract}
Abstrak: Perubahan zaman membawa dampak bagi seluruh negara. Dengan adanya perubahan zaman, pola pikir manusiapun ikut berubah. Perubahan zaman membawa positif dan negatif. Dampak negatif dari arus globalisasi yang terlihat miris adalah perubahan yang cenderung mengarah pada krisis moral dan akhlak. Adapun tujuan dari penelitian ini adalah untuk mengetahui implementasi kurikulum pendidikan agama Islam dan hambatan serta solusi dari pelaksanaannya dalam dimensi akhlak. Metode dalam penelitian ini adalah menggunakan pendekatan kualitatif deskriptif. Pengumpulan data dilakukan dengan cara wawancara, observasi dan dokumentasi. Hasil penelitian menunjukkan bahwa penerapan kurikulum pendidikan agama Islam di SMA Negeri 2 Kotapinang sudah terlaksana dengan baik, dengan mampu nya para siswa-siswi mengembangkan pengetahuan agama sehingga terlaksanakan dalam kehidupan sehari-harinya (religius). Didukungkegiatan-kegiatan yang dilaksanakan disekolah seperti: Sholat Jenazah, Pidato, Musabaqah Tilawatil Qur'an (MTQ), Rohis, Prinsip Hidup bersih dan disiplin para siswa-siswi yang menumbuhkan nilai religius.
\end{abstract}

Kata Kunci: Implementasi Kurikulum, Pendidikan Agama Islam, SMA 


\section{PENDAHULUAN}

Perubahan zaman membawa dampak bagi seluruh negara. Dengan adanya perubahan zaman, pola pikir manusiapun ikut berubah. Perubahan zaman membawa positif dan negatif. Dahulu moral dan akhlak anak indonesia patut diacungkan jempol. Dilihat dari tatakramanya,sopan santun, dan tutur bahasanya. Tapi kini, moral dan akhlak remaja di Indonesia sangat memperihatinkan. Dampak negatif dari arus globalisasi yang terlihat miris adalah perubahan yang cenderung mengarah pada krisis moral dan akhlak, sehingga menimbulkan permasalahan kompleks melanda negeri ini akibat moral.

Sedangkan, Kehidupan dalam era global menuntut berbagai perubahan pendidikan yang bersifat mendasar. Perubahan-perubahan tersebut antara lain: perubahan dari pandangan kehidupan masyarakat lokal ke masyarakat global, perubahan kohesi sosial menjadi partisipasi demokratis dan perubahan dari pertumbuhan ekonomi ke perkembangan kemanusiaan. ${ }^{1}$

Menghadapi berbagai perubuhan atau masalah dan tantangan diatas, perlu dilakukan penataan terhadap sistem pendidikan secarah utuh dan menyeluruh, terutama berkaitan dengan kualitas pendidikan, serta relevansinya dengan kebutuhan masyarakat dan dunia kerja. Dalam hal ini, perlu adanya perubahan sosial yang memberi arah bahwa pendidikan merupakan pendekatan dasar dalam proses perubahan itu. Dalam pendidikan belajar merupakan proses memanusiakan manusia, dimana hanya melalui belajar manusia menemukan dirinya dalam relasinya dengan sang pencipta. Melalui belajar manusia mengaktualisasikan diri dan lingkunganya sedemikian sehingga kualitas hidup dan penghidupan menjadi lebih baik. ${ }^{2}$

Dinamika perkembangan kurikulum saat ini, khususnya dalam pelajaran Pendidikan Agama Islam perlu mendapat perhatian lebih dari praktisi pendidikan agar penetapan kebijakannya sesuai dengan tujuan.Dewasa ini, kurikulum sudah menjadi disiplin ilmu sendiri, baik praktis maupun teoritis. Sesuai dengan tuntutan era global, kurikulum dinamakan kurikulum modern yang mana lebih banyak diorientasikan pada kecakapan hidup (life skill), pengembangan diri, pengembangan politik, hukum, ekonomi, industri, dan sosilbudaya untuk menciptakan peradaban dunia yang tertata rapi. ${ }^{3}$

\footnotetext{
${ }^{1}$ Mulyasa, pengembangan dan implementasi kurikulum 2013 (Bandung: PT. Remaja Rosdakarya, 2013), hal.2.

${ }^{2}$ Slameto, Proses Belajar Mengajar Dalam Sistem Kredit Smester (Jakarta: Bumi Aksara, 1991), hal.5

${ }^{3}$ Abdul Wafi, "KONSEP DASAR KURIKULUM PENDIDIKAN AGAMA ISLAM," EDURELIGLA: Jurnal Pendidikan Agama Islam 1, no. 2 (12 Juli 2017): 133-39, https://doi.org/10.33650/edureligia.v1i2.741.
} 
Dalam pendidikan dari beberpaa aspek dalam pembelajaran, kurikulum memainkan peran yang sangat penting dalam mewujudkan generasi yang handal, kreatif, inovatif dan menjadi pribadi yang bertanggung jawab.Kurikulum menentukan jenis dan kualitas pengetahuan dan pengalaman yang memungkinkan orang atau seseorang mencapai kehidupan dan penghidupan yang lebih baik.Oleh karena itu kurikulum harus selalu disusun dan di sempurnakan sesuai dengan perkembangan zaman.

Kurikulum harus bersifat dinamis, artinya kurikulum selalau mengalammi perubahan sesuai dengan perkembangan zaman, ilmu pengetahuan dan teknologi, tingkat kecerdasan kultur, sistem nilai serta kebutuhan masyarakat. Oleh karena itu, kurikulum harus selalu di monitoring dan di evaluasi untuk perbaikan dan penyempurnaanya. ${ }^{4}$

Melalui pengembangan kurikulum 2013 yang berbasis karakter dan berbasis kompetensi kita berharap bangsa ini menjadi bangsa yang bermartabat yang memiliki nilai tambah agar mampu bersaing dengan bangsa dan negara lain. Hal ini dimungkinkan jika implementasi kurikulum betul-betul dapat menghasilkan insan yang produktif, kreatif, inovatif dan berkarakter. ${ }^{5}$ Pendidikan karakter dalam kurikulumpendidikan agama Islam bertujuan untuk meningkatkan mutu proses dan hasil pendidikan yang mengarah pada pembentukan budi pekerti dan akhlak mulia peserta didik secara utuh, terpadu dan seimbang sesuai dengan standar kompetensi lulusan pada setiap satuan pendidikan

Melalui pelaksanaan kurikulum pendidikan agama Islamyang terencana, maka hasil dari pembelajaran yang terlaksanaakanmembawa perubahanperubahan ke arah tujuan yang diinginkan.Sehingga perubahan-perubahan positif itu telah terjadi pada diri peserta didik. ${ }^{6}$

Sehingga kurikulum pendidikan bertujuan untuk menumbuhkan intelektual, emosional dan spiritual dan dapat membantu peserta didik menjadi lebih maju dan menumbuhkan kekuatan karakter peserta didik, karena karakter sangat berhubungan dengan pengembangan ilmu pengetahuan. ${ }^{7}$ Melalui implementasi kurikulum 2013 yang berbasis kompetensi sekaligus berbasis

${ }^{4}$ Zaenal Arifin, Konsep dan Model Pengembangan Kurikulum (Bandung: PT. Remaja Rosdakarya, 2011), hal. 2

${ }^{5}$ Mulyasa H.E, Pengembangan Implementasi Kurikulum 2013 (Bandung: PT. Remaja Rosdakarya, 2013), hal. 7

${ }^{6}$ Omar Hamalik, Manajemen Pengembangan kurikulum (Bandung: PT. Remaja Rosdakarya, 2012). 97

${ }^{7}$ Siti Anisatun Nafi'ah, "MODEL PENGEMBANGAN KURIKULUM HILDA TABA PADA KURIKULUM 2013 DI SD/MI,” As-Sibyan 2, No. 1 (29 Juni 2019): 21-38. 
karakter diharapkan peserta didik mampu secara mandiri meningkatkan dan menggunakan pengetauanya, mengkaji serta mempersonalisasi nilai-nilai karakter serta akhlak mulia sehingga terwujud dalam perilaku sehari-hari.

Secara harfiah kurikulum berasal dari bahasa latin, curriculum yang berarti bahan pengajaran. Ada pula yang mengatahakan bahwa kata tersebut berasal dari bahasa Perancis courier yang berarti berlari. Dalam KBBI, kata "kurikulum" berarti: perangkat mata pelajaran yang diberikan pada lembaga pendidikan, atau perangkat mata kuliah bidang khusus. Menurut Abudin Nata, secara umum pengertian kurikulum ini dapat dibedakan menjadi 2 bagian, pengertian kurikulum secara sempit dan luas. Secara sempit, seperti dikatakan Crow and Crow bahwa kurikulum adalah rancangan pengajaran yang isinya sejumlah mata pelajaran yang disusun secara sistematis yang diperlukan sebagai syarat untuk menyelesaikan suatu program pendidikan tertentu. ${ }^{8}$

Kurikulum berasal dari bahasa yunani yang semula digunakan dalam bidang olahraga yaitu curere yang berarti jarak yang harus ditempuh dalam kegiatan berlari mulai dari strat hingga finish.Pengertian ini kemudian diterapkan dalam bidang pendidikan. Dalam bahasa Arab istilah "Kurikulum" diartikan dengan manbaj yang berarti jalan yang terang, atau jalan terang yng dilalui oleh manusia pada bidang kehidupanya." Jadi, dalam defenisi diatas dapat disimpulkan bahwa kurikulum merupakan program pendidikan yang berisi rancangan pelajaran yang diberikan kepada peserta didik dalam jenjang pendidikan. Kurikulum juga diartikan sebagai seperangkat rencana dan pengaturan mengenai tujuan, isi dan bahan pelajaran, serta cara yang digunakan sebagai pedoman penyelenggaraan kegiatan pembelajaran untuk mencapai tujuan pendidikan tertentu.

Edward A, Krug dalam buku The Secondary School curriculum (1960) menyatakan bahwa kurikulum dipandang sebagai cara dan upaya guna mencapai tujuan pendidikan. ${ }^{10}$ Kurikulum merupakan program pendidikan sebagai cara untuk mencapai tujuan tersebut, sehingga pendidikan berlangsung secara efektif dan efisien

George Beauchamp dalam bukunya suparnomenjelaskan bahwa ia mencoba mengelompokkan kurikulum dalam tiga kelompok: ${ }^{11}$

${ }^{8}$ Abudin Nata, Ilmu Pendidikan Islam (Jakarta: Gaya Media Pratama, 2005).

${ }^{9}$ Abdul Manab, Manajemen Perubahan Kurikulum (Yogyakarta: Kalimedia, 2014), hal.1

${ }^{10}$ Moh. Yamin, Manajmen mutu kurikulum pendidikan (Yogyakarta: PT. Remaja Rosdakarya, 2009), hal. 24

${ }^{11}$ Suparno, Tanya jawab pengembangan kurikulum \& materi Pembelajaran (Jakarta: PT. Bumi Aksara, 2012).39 
Pertama, bahwa kurikulum adalah a plan for subsequent action. Kedua, kurikulum adalah proses pengajaran dan pembelajaran (curriculum and instruction as synonums or a unified concept). Ketiga, mendefinisikan sebagai istilah yang sangat luas yang meliputi proses psikologikan peserta didik sebagai pengalaman belajar (a very broad term, encompassing the learner's psychological process as she or he acquires educational experiences). Kurikulum merupakan proses dan program pembelajaran yang dilakukan kepada peserta didik.

Istilah kurikulum digunakan dalam dunia pendidikan. Misalnya, para ahli pendidikan Robert M, Horalt Alberty, Muray Print, Hutchins, Romine, A. Ferry T.Indratno dan lain-lain, mereka menafsirkanya berbeda-beda mengenai kurikulum. Namun, semua memiliki hubungan dan usaha yang mengembangkan peserta didik sesuai tujuan yang ingin dicapai. Dengan kata lain bahwa kurikulum adalah alat untuk mencapai tujuan pendidikan. ${ }^{12}$

Dari keterangan pengertian kurikulum tersebut dapat dipahami bahwa kurikulum merupakan program kegiatan pembelajaran sebagai kunci pendidikan akan diarahkan untuk mencapai suatu keberhasilan dalam pendidikan untuk mendapatkan bekal ilmu pengetahuan yang baik untuk membangun kecerdasan baik kognitif, afektif dan psikomotorik.

Kurikulum merupakan acuan yang dijadikan pedoman dalam pelaksanaan pembelajaran. ${ }^{13}$ Sedangkan pengertian kurikulum yang tetuang dalam Undang-undaang sisdiknas Nomor: 20/2003 adalah seperangkat rencana dan pengaturan mengenai tujuan, isi, bahan pelajaran serta cara yang digunakan sebagai pedoman penyelenggaraan kegiatan pembelajaran untuk mencapai tujuan pendidikan tertentu. ${ }^{14}$

Secara istilah kurikulum dapat dimaknai sebagai plan for learning (rencana pendidikan). Karena sebagai rencana pendidikan, dengan kurikulum akan memberikan pedoman yang menjadi pegangan tentang jenis lingkup, urutan, isi dan proses pendidikan. ${ }^{15}$ Secara historis, istilah kurikulum pertama kalinya diketahui dalam kamus Webster tahun 1856.Pada istilahnya kurikulum digunakan dalam dunia olahraga, yakni suatu alat yang membawa orang dari start samai ke finish. Pada tahun 1955, istilah kurikulum telah dipakai dalam bidng

\footnotetext{
${ }^{12}$ Siswanto Siswanto dan Eli Susanti, "Manajemen Pengembangan Kurikulum Sekolah Inklusi," Tadbir: Jurnal Studi Manajemen Pendidikan 3, no. 2 (24 November 2019): 113-28, https://doi.org/10.29240/jsmp.v3i2.927.

${ }^{13}$ Subandi Subandi, "PENGEMBANGAN KURIKULUM 2013 (Studi Analitis dan Subtantif Kebijakan Kurikulum Nasional)," TERAMPIL: Jurnal Pendidikan dan Pembelajaran Dasar 1, no. 1 (2014): 18-36.

${ }^{14}$ Abdul Manab, Manajemen Perubahan Kurikulum.1

${ }^{15}$ Nana Syaodih Sukmadhinata, Pengembangan kurikulum, Teori dan Praktek, (Bandung: Remaja Rosdakarya, 2004).4
} 
pendidikan, yang bermaksud dengan sejumlah mata pelajaran disuatau perguruan. ${ }^{16}$

Didalam kurikulum 2013 terdapat kurikulum Pendidikan Agama Islam yang meliputi bebrapa aspek diantaranya, aspek Al-Qur'an Hadits, aspek fiqh, aspek akidah Akhlak dan aspek Sejarah (SKI). Melalui aspek itu, berhubungan dengan pembentukan manusia yang berkrakter Islam menjadi hamba Allah secara total. ${ }^{17}$

Hal ini berkaitan dengan tujuan pendidikan agama Islam disekolah untuk mengembangkan potensi peserta didik agar menjadi manusia yang berkepribadian baik, benar yang memiliki kemampuan kognitif yang afektif, dan mampu mengamalkan dan menerapkan ajaran Islam dalam kehidupan. Pembelajaran PAI di sekolah ini diharapkan siswa tidak hanya memiliki kemampuan tapi juga memiliki kemauan serta kebiasaan dalam menrapkan ajaran dan nilai-nilai agama tersebut dalam kehidupan sehari-hari. ${ }^{18}$ Dengan demikian Implementasi kurikulum 2013 dalam Pembelajaran Pendidikan Agam Islam akan efektif dan efisien. ${ }^{19}$ Maka dalam kurikulum 2013 ini berhubungan, karena bertujuan untuk meningkatkan mutu proses dan hasil pendidikan yang mengarah pada pembentukan budi pekerti danAkhlak mulia peserta didik secara utuh, terpadu, dan seimbang sesuai dengan standar kompetensi lulusan pada setiap satuan pendidikan. ${ }^{20}$

Dalam pengimplementasian perencanaan kuriklum PAI menggunakan pendekatan, metode dan penilaian untuk mencapai tujuan yang ingin dicapai. Kemudian implementasi pelaksanaan kurikulum PAI dalam proses dilengkapi dengan mengamati, menanya, mengolah, menalar, menyajikan, menyimpulkan dan mencipta, pembelajaran tidak hanya di ruang kelas, tetapi dilingkungan sekolah dan masyarakat, guru bukan satu-satunya sumber belajar dan sikap tidak diajarkan secara verbal, tetapi melalui contoh dan teladan, kemudian

${ }^{16}$ Ahmad Tafsir, Ilmu Pendidikan dalam Perspektif Islam (Bandung: Remaja Rosdakarya, 2004), hal.53

${ }^{17}$ Maragustam, Filsafat Pendidikan Islam Menuju Pembentukan Karakter (Yogyakarta: Pascasarjana, FITK UIN Sunan Kalijaga, 2019), hal.199

${ }^{18}$ Ayu Wilatikta dan Ayu Wilatikta, "Manajemen Kurikulum Pendidikan Agama Islam Jenjang Pendidikan Dasar: Kontekstualisasi Strategi Pembelajaran Semasa Pandemi," Ta'lim 2, no. 2 (30 Oktober 2020): 1-12.

${ }^{19}$ Muhaimin, Rekontruksi Pendidikan Islam (Jakarta: Rajawali Pers, 2009), hal.313

${ }^{20}$ Nuraini Nuraini dan M. Fata Muhtarima, "Implementasi Kurikulum 2013 Pada Mata Pelajaran Pendidikan Agama Islam Di Sd Muhammadiyah Terpadu Ponorogo," Istawa: Jurnal Pendidikan Islam 1, no. 2 (2016): 52-80. 
pengevaluasian dalam pembelajaran PAI dengan menyambungkan antara kompetensi dan karakter sesuai dengan kurikulum 2013. ${ }^{21}$

Kurikulum dan pembelajaran memiliki kaitan yang erat dan saling menunjang maka pembahasan mengenai pembelajaran dalam konteks implementasi Kurikulum 2013 tentu tidak bisa dilepaskan dari karakteristik Kurikulum 2013. Oleh karena itu, apabila Kurikulum 2013 memiliki karakteristik utama yaitu buman competence dan mastery learning, tentu saja pengelolaan pembelajarannya haruslah mencerminkan dan berbasis pada dua karakteristik tersebut. $^{22}$

Dalam aplikasinya, kurikulum selalu didukung dengan beberapa faktor yang dengannya menjadi berhasil, yaitu guru yang kompeten, pendampingan, pembinaan dan pengawasan, peserta didik, lulusan yang diharapkan, ketersediaan sumber belajar dan bahan ajar, serta manajemen dan budaya sekolah yang baik. Pun dalam kurikulum Pendidikan Agama Islam. Di sini guru lebih dituntut untuk bisa menjadi seseorang yang tidak hanya mentrasferkan ilmu dan pengetahuan saja, tetapi harus sampai pada bisa menanamkan dan menerapkannya pada peserta didik. Dalam penjelasan diatas peneliti mengambil dua rumusan masalah, pertama membahas implemenntasi kurikulum dan faktor pendukung-penghambat kurikulum khususnya pada Pendidikan Agama Islam pada dimensi Akhlak di SMA Negeri 2 Kotapinang Labuhanbatu Selatan, Sumatera Utara.

\section{METODE PENELITIAN}

Metode penelitian yang digunakan penulis adalah merupakan penelitian lapangan dengan menggunakan jenis metode penelitian kualitatif. Metode kualitatif berfungsi memperoleh data secara faktual dan mengandung makna yang sesuai dengan apa yang terjadi dilapangan. Oleh karena itu, lebih menekankan pada makna yang terkandung didalamnya. ${ }^{23}$ Dengan penelitian kualitatif ini penulis akanmudah untuk mengungkapkan secara sistematis dan faktual berkaitan dengan penerapan kurikulum Pendidikan Agama Islam (PAI).

Pengumpulan data dilakukan dengan teknik wawancara, observasi catatan lapangan, dan dokumentasi. Observasi dilakukan dengan cara

${ }^{21}$ Titiek Rohanah Hidayati, "Implementasi Pengembangan Kurikulum 2013 dalam Pembelajaran Pendidikan Agama Islam dan Budi Pekerti di SMA Negeri 4 Jember," Jurnal Fenomena, 2015.

${ }^{22}$ Suyatmini Suyatmini, "Implementasi Kurikulum 2013 Pada Pelaksanaan Pembelajaran Akuntansi Di Sekolah Menengah Kejuruan,” Jurnal Pendidikan Ilmu Sosial 27, no. 1 (2017): 60-68.

${ }^{23}$ Sugiyono, Metode Penelitian Pendidikan (Bandung: Alfabeta, 2017), hal.15 
memperhatikan dan mengamati seluruh kondisi dan kegiatan yang ada dalam sekolahyang berkaitan erat dengan implementasi kurikulum dan pengembangan kurikulum. Serta wawancara yang dilakukan dengan beberapa pendidik, terutama pendidik pada mata pelajaran Pendidikan Agama Islam.

\section{HASIL dan PEMBAHASAN}

\section{Pelaksanaan Kurikulum PAI di SMA Negeri 2 Kotapinang Labuhanbatu Selatan, Sumatera Utara.}

Pendidikan Agama Islam merupakan mata pelajaran yang memberikan kontribusi terhadap pembentukan karakteristik dan moral dari peserta didik.Di dalam PAI banyak memuat materi-materi yang mengharuskan siswanya untuk tidak hanya mempelajari PAI dari aspek pengetahuan saja, tetapi juga pada aspek afektif dan psikomotorik. ${ }^{24}$ Pendidikan Agama Islam mencakup ruang lingkup yaitu materi-materi pokok yang harus dipelajari oleh siswa. Ini mengacu pada PERMENDIKBUD No. 64 tahun 2013 tentang standar isi Pendidikan bahwa Materi pokok PAI pada tingkat kompetensi SMA, ruang lingkup yang dikembangkan adalah: Al-Qur'an dan al-Hadits, Aqidah Akhlaq, SKI, dan Fiqih. ${ }^{25}$

Dasar dan tujuan ideal Pendidikan Agama Islam adalah identik dengan ajaran Islam itu sendiri. Keduanya berasal dari sumber yang sama, yaitu AlQur'an dan Hadis. Yang kemudian dasar tadi dikembangkan dalam pemahaman para ulama. Tujuan PAI ialah sesuatu yang diharapkan tercapai setelah sesuatu usaha atau kegiatan selesai. Maka, pendidikan merupakan suatu usaha dan kegiatan yang terproses melalui tahap-tahap dan tingkatan-tingkatan yang bertujuan. Tujuan pendidikan bukanlah suatu benda yang berbentuk tetap dan statis, tetapi ia merupakan suatu keseluruhan dari kepribadian seseorang, berkenaan dengan seluruh aspek kehidupannya. ${ }^{26}$

Pentingnya pembelajaran pendidikan agama Islam dalam meningkatkan ketaqwaan, maka dapat diartikan bahwa pembelajaran PAI sebagai perlakuan profesional guru agama terhadap peserta didiknya sehingga menghasilkan peserta didik yang mempunyai kemampuan untuk mengetahui, menghayati, dan mengembangkan pengetahuan, untuk dipedomani dan dilaksanakan dalam

${ }^{24} \mathrm{Hj}$. Titiek Rohanah Hidayati, Implementasi Pengembangan Kurikulum 2013, Jurnal Fenomena, Vo.14 no.1 April 2015, hal. 10.

${ }^{25}$ Hidayati, "Implementasi Pengembangan Kurikulum 2013 dalam Pembelajaran Pendidikan Agama Islam dan Budi Pekerti di SMA Negeri 4 Jember."

${ }^{26}$ Zakiah Drajat dkk, Ilmu Pendidikan Islam (Jakarta: Bumi Aksara, 2012), hal.29 
kehidupannya sebagai seorang muslim yang beriman dan bertaqwa dalam kehidupan pribadi dan bermasyarakat. ${ }^{27}$

Penyampaian rencana kegiatan dalam apersepsi akan membuat peserta didik terdorong mengikuti pembelajaran dari awal sampai akhir karena mereka mengetahui kegiatan apa saja yang akan dilakukan selama pembelajaran. Hal ini juga bisa menjadi kontrol bagi guru dan peserta didik terhadap kegiatan pembelajaran yang dilakukan agar sesuai dengan waktu yang tersedia dan rencana yang telah ditetapkan. Menyampaikan pemanasan dan apersepsi perlu dilakukan untuk menjajaki pengetahuan dan memotivasi peserta didik sebelum mengikuti pembelajaran. Kegiatan pembelajaran dapat dilakukan dengan cara sebagai berikut: (1) mulailah pembelajaran dengan hal-hal yang diketahui dan dipahami peserta didik, (2) memotivasi peserta didik dengan bahan ajar yang menarik dan berguna bagi kehidupan mereka, (3) menggerakkan peserta didik agar tertarik dan bernafsu untuk mengetahui hal-hal baru. Untuk itu, dapat dilakukan dengan memberikan pertanyaan, mempraktikkan, menyampaikan rencana kegiatan dan manfaat pembelajaran dalam kehidupan. ${ }^{28}$

Jika dilihat dari pembuatan kurikulum dalam pembelajarannya di SMA Negeri 2 Kotapinang ini, guru memakai kurikulum 2013. Dalam penerapan kurikulum guru mempunyai strategi sendiri, yaitu dengan mengaplikasikannya sesuai yang dipedomankan dalam kurikulum diknas.

Dengan struktur kurikulum dalam pemberian materinya, pelajaran PAI dialokasikan 3x40 menit (2x pertemuan) dalam seminggu. Dengan jumlah guru PAI di SMA Negeri 2 Kotapinang terdiri dari 3 guru PAI yang lebih kepada ranah nilai akhlak dan Tahsin, yang mana jumlah pendidik dominan guru yang beragama Islam. Tema pelajaran PAI, yaitu mencakup unsur-unsur PAI seperti Aqidah Akhlak, Fiqih, Qur'an Hadist dan SKI ada didalamnya. Dengan bergantian tema di setiap tatap mukanya, sesuai dengan judul yang ada didalamnya. Dengan mengintegrasikan antar mata pelajaran, semua pelajaran umum juga berasaskan Al-Qur'an dan Hadis.

Standar isi dari kurikulum pelajaran PAI di SMA Negeri 2 Kotapinang terdiri dari Standar Kompetensi, Kompetensi Dasar, Indikator Pencapaian, Tujuan Pembelajaran, Materi Pembelajaran, Metode Pembelajaran, Langkahlangkah Pembelajaran yang terdiri dari kegiatan pendahuluan yaitu, apresiasi dan motivasi, kemudian kegiatan inti yaitu, eksplorasi, elaborasi, dan konfirmasi, dan

\footnotetext{
${ }^{27}$ Rosmiaty Azis, "Implementasi pengembangan kurikulum," Inspiratif Pendidikan 7, no. 1 (2018): 44-50.

${ }^{28}$ Sri Budiani, Sudarmin Sudarmin, dan Rodia Syamwil, "Evaluasi Implementasi Kurikulum 2013 di Sekolah Pelaksana Mandiri," Innovative Journal of Curriculum and Educational Technology 6, no. 1 (2017): 45-57.
} 
diakhiri kegiatan penutup. Serta di dalam pembelajarannya di dukung oleh alat dan sumber belajar diantaranya, buku PAI, Al-Qur'an, Software pengajaran, kaset/CD dan menggunkan video melalui layar proyektor atau infocus.

Melihat standar proses yang ada maka SMA Negeri 2 Kotapinang terdapat standar dalam pengelolaan proses pendidikan harus dipenuhi oleh setiap lembaga pendidikan formal pada jenjang pendidikan tertentu dalam memberikan pelayanan kepada masyarakat di manapun lembaga pendidikan itu berada baik di perkotaan maupun pedesaan secara nasional. Standar proses dikaitkan dengan pelaksanaan pembelajaran. Di SMA Negeri 2 Kotapinang guru menggunakan strategi pembelajaran yang dibuat oleh guru sendiri. Dengan metode tersebut membuat pembelajaran semakin mengasyikan bagi peserta didik. Ditambah metode diskusi dan ceramah serta metode Demonstrasi sebagai pendukung. Tak hanya itu, guru pun tetap mengontrol pada siswa dikesehariannya terutama dalam hal ibadah.

Melihat dari semua standar yang ada dalam sebuah pengembangan kurikulum, standar penilaian juga amat sangat penting. Karena dengan ini, seorang guru dapat mengetahui seberapa mengerti anak dilihat dari kognitif. Standar penilaian di SMA Negeri 2 Kotapinang dalam pelajaran PAI ini terdiri dari kesemangatan belajar anak, cara berfikir, bertindak, keaktifan yang dinilai dari pengamatan. Serta pengetahuan dan pemahaman yang dinilai dengan tes lisan. Dengan aspek kerjasama, keaktifan dankeberanian.

Setelah proses perencanaan yang dilakukan sudah matang dan siap untuk dibelajarkan pada anak-anak, kemudian di tahap pembelajarannya, sang guru mengajarkan pelajaran PAI tidak hanya teoritis saja, dengan basic Islam Terpadu yang dimiliki, SMA Negeri 2 Kotapinang dalam pengembangan kurikulum PAI tidak hanya di teorinya saja, melainkan juga diimplementasikan dalam keseharian peserta didiknya di sekolah dan di rumah. Karena pembelajaran PAI tidak hanya untuk pengetahuan saja, tetapi adanya pembiasaan yang harus ditanamnkan. Dengan berangkat pagi ke sekolah dan sesampainya di sekolah, para peserta didik harus berbaris didepan kelas untuk melatih kedisiplinan siswa dan siswi. Setelah itu mereka memasuki kelas dengan berdoa bersama sembari menunggu guru, mereka murojaah hafalan ataupun pelajaran. Dan digalakkan adanya literasi di setiap kelas dengan wali kelas masing-masing, untuk menumbuhkan minat baca lebih kepada peserta didik.

Selain itu, guru PAI di SMA Negeri 2 Kotapinang ini, mempunyai strategi yang sangat kreatif dan inovatif. Yaitu selain dengan metode ceramah, diskusi, kooperatif learning, demonstrasi, tanya jawab, dan problem solving yang digunakan, sang guru juga menggunakan metode gubahan lagu. Yaitu dengan membuat Sholawat dengan Nasyid yang mana isi dari lagu tersebut adalah 
berkaitan dengan materi PAI yang diajarkan, dan kisah tentang sejarah Perjuangan para Rasulullah SAW dan Para Sahabat, serta pembelajaran Pidato dan MTQ. Yang mana dianggap oleh sang guru dapat memudahkan peserta didik dalam memahami dan menghafal serta mengingat.

\section{Faktor Pendukung dan Penghambat Kurikulum PAI di SMA Negeri 2 Kotapinang Labuhanbatu Selatan, Sumatera Utara}

Implementasi kurikulum di sekolah ini dirasa telah sesuai dengan apa yang telah ditetapkan oleh pemerintah, dari proses persiapan hingga evaluasi pembelajaran. Guru dituntut untuk mampu memberikan nilai-nilai dalam materi tidak hanya mentrasfer ilmu saja namun guru di SMA Negeri 2 Kotapinang dituntut untuk mampu mendidik siwa-siswinya, terlebih pada guru PAI sebisa mungkin untuk menjadi qudwah khasanah bagi siswa-siswinya. Proses pembelajaran PAI tidak hanya berlangsung di dalam kelas namun juga di luar kelas, disini siswa tidak hanya diberikan materi di kelas saja namun juga diharapkan mampu mengimplementasikan religius tersebut pada lingkungannya atas apa yang telah dipelajari dalam pendidikan agama Islam.

Proses penerapan kurikulum PAI, seorang guru harus mempersiapkan sebuah perencanaan pembelajaran sebelum mengajarkannya kepada para siswanya. ${ }^{29}$ Guru PAI di SMA Negeri 2 Kotapinang ini mengungkapkan bahwasanya dalam perencanaannya beliau mempersiapkan dengan pembuatan RPP, RPS, Silabus, serta Promes dan Prota dan beberapa lembar evaluasi atau penilaian di akhir, berupa ulangan harian, LKS, tes lisan dan tes tulis atau ujianakhir.

Walaupaun dalam proses implementasinya sang guru juga mengalami faktor pendukung dan penghambat. Faktor pendukung yang dialami sang guru antara lain:

1. Dari segi sumber belajar, sudah cukup memadai. Begitupula fasilitas yang ada di sekolah, adanya Buku panduan belajar, Lcd Proyektor, papan tulis dan meja bangku sangatmencukupi.

2. Dari segi metode yang diajarkan guru. Guru harus bisa lebih kreatif dan inovatif dalam mengajarkan pelajaran PAI melihat anak yang diajar adalah setingkat sekolah menengah.

Dari faktor penghambat, yaitu:

1. Alokasi waktu yang hanya 3 kali seminggu. Sedangkan subject mata

${ }^{29}$ Aldo Redho Syam, "Guru dan Pengembangan Kurikulum Pendidikan Agama Islam di Era Revolusi Industri 4.0,” TADRIS: Jurnal Pendidikan Islam 14, no. 1 (10 Juni 2019): 1-18, https://doi.org/10.19105/tjpi.v14i1.2147. 
pelajaran yang lumayan banyak untuk diajarkan dan terkadang harus mengulangi karena peserta didik belum memahami

2. Peserta didik yang beraneka ragam dalam hal menangkap dan menyerap materipelajaran

Solusi dari hamatan yang di atas dengan memberikan waktu lebih, jika dirasa tidak susah untuk memberikan waktu luang maka lembaga perlu memberikan jam tambahan seperti mengadakan breafing atau mentoring tiap harinya, mentoring dapat disisipkan dengan nilai-nilai dalam mata pelajaran PAI. Menjadi guru pada kurikulum 2013 ini dituntut untuk inovatif dan kreatifmampu memadukan antara mata pelajaran, lingkunagan dan kehidupan sehari-hari. Sehingga materi yang diberikan terpatri pada masing-masing siswa. Dengan adanya hambatan diharapkan guru dan siswa bekerjasama dalam proses pencapaian tujuan pembelajaran SMA Negeri 2 Kotapinang terus berupaya untuk perbaikan dalam implementasi kurikulum Pendidikan Agama Islam.

Implementasi penilaian, guru PAI di SMA Negeri 2 Kotapinang mewujudkannya dengan mengadakan evalusai pembelajaran dengan adanya lembar pengamatan yang berfungsi untuk menilai tidak hanya kognitif siswa tetapi juga afektif dan psikomotorik. Dan diberikan soal ulangan harian setelah pemberian materi, serta ujian akhir baik tulis maupun lisan di akhir semester untuk penilaian akhir tahun.

\section{KESIMPULAN}

Penerapan kurikulum pendidikan agama Islam pada sistem pembelajaran di SMA Negeri 2 Kotapinang dilaksanakan, tujuanya dalah pembentukan akhlak atau tingkah laku siswa yang dapat dinilai dari kebiasaan siswa yang ditanamkan. Melalui metode belajar dan kegiatan-kegiatan yang dilaksanakan di sekolah, maupun para staf karyawan dan seluruh elemen perangkat sekolah dilibatkan dalam membantu dan mendukung dalampenerapan kurikulum PAI di sekolah tersebut. Dengan begitu, penerapan kurikulum pendidikan agama Islam di SMA Negeri 2 Kotapinang sudah terlaksana dengan baik, dengan kemampuan para siswa-siswi mengembangkan pengetahuan agama sehingga terlaksanakan dalam kehidupan sehari-harinya (religius). 


\section{BIBLIOGRAPHY}

Abdul Manab. Manajemen Perubahan Kurikulum. Yogyakarta: Kalimedia, 2014.

Abudin Nata. Ilmu Pendidikan Islam. Jakarta: Gaya Media Pratama, 2005.

Ahmad Tafsir. Ilmu Pendidikan dalam Perspektif Islam. Bandung: Remaja Rosdakarya, 2004.

Azis, Rosmiaty. "Implementasi Pengembangan Kurikulum.” Inspiratif Pendidikan 7 , no. 1 (2018)

Budiani, Sri, Sudarmin Sudarmin, dan Rodia Syamwil. "Evaluasi Implementasi Kurikulum 2013 di Sekolah Pelaksana Mandiri." Innovative Journal of Curriculum and Educational Technology 6, no. 1 (2017)

Hidayati, Titiek Rohanah. "Implementasi Pengembangan Kurikulum 2013 dalam Pembelajaran Pendidikan Agama Islam dan Budi Pekerti di SMA Negeri 4 Jember." Jurnal Fenomena, 2015.

Maragustam. Filsafat Pendidikan Islam Menuju Pembentukan Karakter. Yogyakarta: Pascasarjana, FITK UIN Sunan Kalijaga, 2019.

Moh. Yamin. Manajmen mutu kurikulum pendidikan. Yogyakarta: PT. Remaja Rosdakarya, 2009.

Muhaimin. Rekontruksi Pendidikan Islam. Jakarta: Rajawali Pers, 2009.

Mulyasa H.E. Pengembangan Implementasi Kurikulum 2013. Bandung: PT. Remaja Rosdakarya, 2013.

Nafi'ah, Siti Anisatun. "MODEL PENGEMBANGAN KURIKULUM HILDA TABA PADA KURIKULUM 2013 DI SD/MI.” As-Sibyan 2, no. 1 (29 Juni 2019).

Nana Syaodih Sukmadhinata. Pengembangan kurikulum, Teori dan Praktek,. Bandung: Remaja Rosdakarya, 2004.

Nuraini, Nuraini, dan M. Fata Muhtarima. "Implementasi Kurikulum 2013 Pada Mata Pelajaran Pendidikan Agama Islam Di Sd Muhammadiyah Terpadu Ponorogo." Istawa: Jurnal Pendidikean Islam 1, no. 2 (2016).

Omar Hamalik. Manajemen Pengembangan kurikulum. Bandung: PT. Remaja Rosdakarya, 2012.

Prof. Mulyasa. pengembangan dan implementasi kurikulum 2013. Bandung: PT. Remaja Rosdakarya, 2013.

Siswanto, Siswanto, dan Eli Susanti. "Manajemen Pengembangan Kurikulum Sekolah Inklusi." Tadbir: Jurnal Studi Manajemen Pendidikan 3, no. 2 (24 November 2019): 113-28. https://doi.org/10.29240/jsmp.v3i2.927.

Slameto. Proses Belajar Mengajar Dalam Sistem Kredit Smester. Jakarta: Bumi Aksara, 1991.

Subandi, Subandi. "PENGEMBANGAN KURIKULUM 2013 (Studi Analitis dan Subtantif Kebijakan Kurikulum Nasional)." TERAMPIL: Jurnal Pendidikan dan Pembelajaran Dasar 1, no. 1 (2014). 
Sugiyono. Metode Penelitian Pendidikan. Bandung: Alfabeta, 2017.

Suparno. Tanya jawab pengembangan kurikulum \& materi Pembelajaran. Jakarta: PT. Bumi Aksara, 2012.

Suyatmini, Suyatmini. "Implementasi Kurikulum 2013 Pada Pelaksanaan Pembelajaran Akuntansi Di Sekolah Menengah Kejuruan." Jurnal Pendidikan Ilmu Sosial 27, no. 1 (2017).

Syam, Aldo Redho. "Guru dan Pengembangan Kurikulum Pendidikan Agama Islam di Era Revolusi Industri 4.0." TADRIS: Jurnal Pendidikan Islam 14, no. 1 (10 Juni 2019): 1-18. https:// doi.org/10.19105/tjpi.v14i1.2147.

Wafi, Abdul. "KONSEP DASAR KURIKULUM PENDIDIKAN AGAMA ISLAM." EDURELIGLA: Jurnal Pendidikan Agama Islam 1, no. 2 (12 Juli 2017): 133-39. https://doi.org/10.33650/edureligia.v1i2.741.

Wilatikta, Ayu, dan Ayu Wilatikta. "Manajemen Kurikulum Pendidikan Agama Islam Jenjang Pendidikan Dasar: Kontekstualisasi Strategi Pembelajaran Semasa Pandemi." Ta'lim 2, no. 2 (30 Oktober 2020).

Zaenal Arifin. Konsep dan Model Pengembangan Kurikulum. Bandung: PT. Remaja Rosdakarya, 2011.

Zakiah Drajat dkk. Ilmu Pendidikan Islam. Jakarta: Bumi Aksara, 2012. 